\title{
Prawne uwarunkowania uzyskania wsparcia na prowadzenie agroturystyki z Programu Rozwoju Obszarów Wiejskich 2014-2020
}

1. Proces integracji Polski $\mathrm{z}$ Unią Europejską odegrał istotną rolę w umocnieniu znaczenia działalności przyjmowania i gościnności na obszarach wiejskich, przede wszystkim dzięki regulacjom europejskim wspierającym ekonomicznie wymienione inicjatywy i wymagającym od państw członkowskich dostosowania krajowych programów rozwoju obszarów wiejskich do wytycznych wspólnotowych oraz do opracowania planów rozdziału środków finansowych pomiędzy różne inicjatywy i instrumenty, obejmujących także turystykę wiejską ${ }^{1}$.

Niniejsze rozważania dotyczą możliwości uzyskania przez rolników dofinansowania na podejmowanie i prowadzenie działalności agroturystycznej z Programu Rozwoju Obszarów Wiejskich na lata 2014-2020. Wsparcie z funduszy unijnych konkretnie na rzecz agroturystyki nie było dotychczas przedmiotem badań prawnika agrarysty. Temat ma ważny wymiar praktyczny z uwagi na zainteresowanie rolników uzyskaniem dofinansowania na tę działalność, a także teoretyczny w zakresie ustalenia, czy kryteria podmiotowe i przedmiotowe określone w PROW dla działań objętych wsparciem przystają do agroturystyki, a zatem czy ten rodzaj działalności został uwzględniony jako instrument rozwoju obszarów wiejskich.

Dlatego celem rozważań jest ustalenie, czy i w jakim zakresie PROW 2014-2020 przewiduje wsparcie dla rolników podejmujących lub prowa-

${ }^{1}$ Szerzej na temat agroturystyki w prawie wspólnotowym zob. A. Kapała, Agroturystyka w prawie wspólnotowym, „Przegląd Prawa Rolnego” 2008, nr 2, s. 147-161. 
dzących agroturystykę. Pod tym kątem analizie zostaną poddane określone w Programie działania dotyczące różnicowania działalności. Poprzedzać ją będzie krótkie omówienie sposobu uwzględnienia agroturystyki we wcześniejszych programach określających rozdział środków unijnych na rozwój obszarów wiejskich w Polsce.

Dla celów niniejszych rozważań przyjmuje się definicję pojęcia ,agroturystyka" wyprowadzoną z art. 3 ustawy o swobodzie działalności gospodarczej ${ }^{2}$. Chodzi zatem o działalność wynajmu pokoi, sprzedaży posiłków domowych i innych usług związanych z pobytem turystów, oferowanych przez rolnika w prowadzonym przez niego gospodarstwie rolnym. Usługi turystyczne świadczone na obszarach wiejskich, które nie spełniają kryteriów wymienionych w art. 3 u.s.d.g., zaliczane są do szerszej kategorii tzw. turystyki wiejskiej³ ${ }^{3}$.

2. Polski rząd po raz pierwszy $\mathrm{w}$ dokumencie politycznym przyjętym w 1997 r. „Strategia integracji w sektorze rolnym i w gospodarce żywnościowej” użył pojęć wielofunkcyjności oraz alternatywnych źródeł dochodów. $\mathrm{W}$ kolejnym programie $\mathrm{SAPARD}^{4} \mathrm{w}$ ramach działania „różnicowanie działalności gospodarczej na obszarach wiejskich" zostało przewidziane wsparcie na „usługi wiejskie, łącznie z agroturystyką" ${ }^{5}$. W ten sposób termin ,agroturystyka” (bez wyjaśnienia jej definicji) pojawił się po raz pierwszy $\mathrm{w}$ dokumencie o charakterze politycznym, a nie prawnym.

Możliwości rozwoju agroturystyki znacznie wzrosły w wyniku wprowadzenia programów rozwoju obszarów wiejskich, a także Sektorowego Programu Operacyjnego „Restrukturyzacja i modernizacja sektora żywnościowego i rozwoju obszarów wiejskich” (dalej jako: SPO Rol.) stanowią-

${ }^{2}$ Ustawa z 2 lipca 2004 r. o swobodzie działalności gospodarczej, Dz. U. 2004, Nr 173 poz. 1807 ze zm. (dalej jako: u.s.d.g.).

${ }^{3}$ Szerzej na temat pojęcia agroturystyki zob. A. Kapała, Prawne pojęcie agroturystyki, „Przegląd Prawa Rolnego” 2008, nr 1, s. 100-115.

${ }^{4}$ Specjalny Przedakcesyjny Program na Rzecz Rolnictwa i Rozwoju Obszarów Wiejskich SAPARD (Special Accession Programme for Agriculture and Rural Development) powstał jako instrument pomocy dla dziesięciu krajów starających się o członkostwo w Unii Europejskiej. Wdrażanie programu rozpoczęło się w 2002 r., a zakończyło w 2004. Podstawę prawną Programu stanowiły akty prawne UE: rozporządzenie Rady (WE) nr 1268/1999 z 21 czerwca 1999 w sprawie wspólnotowych środków pomocowych na rzecz działań przedakcesyjnych w dziedzinie rolnictwa i rozwoju obszarów wiejskich w państwach Europy Środkowej i Wschodniej ubiegających się o członkostwo w Unii Europejskiej w okresie przedakcesyjnym, Dz. Urz. WE L 161 z 26 czerwca 1999 r., oraz rozporządzenie Komisji (WE) nr 2222/2000 z 7 czerwca 2000 r. ustanawiające zasady finansowe dla stosowania rozporządzenia Rady (WE) nr 1268/1999, Dz. Urz. WE L 253 z 7 października 2000 r.

${ }^{5}$ Punkt 4.1. SAPARD. 
cych element Narodowego Programu Rozwoju6 ${ }^{6}$ Wsparcie na działania w ramach agroturystyki i usług związanych z turystyką i wypoczynkiem nie było przewidziane w Programie Rozwoju Obszarów Wiejskich 20042006, który wcale nie przeznaczał pomocy na różnicowanie działalności. Natomiast w SPO Rol. określono środki na „,różnicowanie działalności rolniczej i zbliżonej do rolnictwa $\mathrm{w}$ celu zapewnienia różnorodności działań lub alternatywnych źródeł dochodów" ". Działanie skierowane było na wspieranie projektów w zakresie m.in. agroturystyki i usług związanych z turystyką i wypoczynkiem, którego beneficjentem mogły być osoby fizyczne - rolnicy oraz domownicy, a także osoby prawne, których celem było prowadzenie działalności rolniczej i które taką działalność prowadziły. Warto zwrócić uwagę na sposób zdefiniowania w SPO Rol. wspieranej działalności, podkreślający, że jest to „dodatkowa działalność, wykorzystująca istniejące zasoby gospodarstwa rolnego" i stwarzająca „warunki do rozwoju wielofunkcyjnych i trwałych ekonomicznie gospodarstw rolnych"s.

PROW 2007-2013, na podstawie art. 52-53 rozporządzenia WE 1698/20059 i art. 35 rozporządzenia WE 1974/2006 ${ }^{10}$, wprowadził środki w ramach osi 3: „Różnicowanie w kierunku działalności nierolniczych"11, ukierunkowanych na zrównoważony rozwój społeczno-ekonomiczny przez udzielenie pomocy z tytułu podjęcia przez rolników, domowników lub małżonka rolnika działalności nierolniczych

${ }^{6}$ Opracowany przez rząd polski na podstawie rozporządzenia WE nr 1260/1999 Rady z 21 czerwca 1999 r., wprowadzającego ogólne wytyczne w zakresie funduszy strukturalnych Dz. Urz. WE L 161 z 26 czerwca 1999 r. Zob. Sektorowy Program Operacyjny „Restrukturyzacja i modernizacja sektora żywnościowego oraz rozwój obszarów wiejskich 2004-2006" opracowany na podstawie załącznika do Rozporządzenia Ministra Rolnictwa i Rozwoju Wsi z 3 września 2004 r. (Dz. U. Nr 197, poz. 2032) w sprawie przyjęcia Sektorowego Programu Operacyjnego „Restrukturyzacja i modernizacja sektora żywnościowego oraz rozwój obszarów wiejskich 2004-2006".

${ }^{7}$ Wprowadzone na podstawie art. 33 Rozporządzenie Rady (WE) nr 1257/1999 z 17 maja 1999 r. w sprawie wsparcia rozwoju obszarów wiejskich z Europejskiego Funduszu Orientacji i Gwarancji Rolnej (EFOGR) oraz zmieniające i uchylające niektóre rozporządzenia, Dz. Urz. WE L 160 z 26 czerwca 1999 r.

${ }^{8}$ Zob. s. 101 SPO Rol. (Działanie 2.4.).

${ }^{9}$ Rozporządzenie Rady (WE) nr 1698/2005 z 20 września 2005 r. w sprawie wsparcia rozwoju obszarów wiejskich przez Europejski Fundusz Rolny na rzecz Rozwoju Obszarów Wiejskich (EFRROW), Dz. Urz. WE L 277/1 z 21 października 2005 r.

${ }^{10}$ Rozporządzenie Komisji (WE) NR 1974/2006 z 15 grudnia 2006 r. ustanawiające szczegółowe zasady stosowania rozporządzenia Rady (WE) nr 1698/2005 w sprawie wsparcia rozwoju obszarów wiejskich przez Europejski Fundusz Rolny na rzecz Rozwoju Obszarów Wiejskich (EFRROW), Dz. Urz. WE L 368/15 z 23 grudnia 2006 r.

${ }^{11}$ Zob. pkt 5.3.3 PROW 2007-2013. 
lub związanych $\mathrm{z}$ rolnictwem $\mathrm{w}$ zakresie produkcji i usług. Ustawa z 2007 r. o rozwoju obszarów wiejskich ${ }^{12}$ - w ramach działań wymienionych w art. 5, wspieranych przez Europejski Fundusz Rolniczy na rzecz Rozwoju Obszarów Wiejskich - nie przewidziała wprost ani turystyki wiejskiej, ani agroturystyki, ale ogólną kategorię inicjatyw z zakresu różnicowania w kierunku działalności nierolniczych. Natomiast rozporządzenie ${ }^{13}$ stanowiło, że do wsparcia uprawniony był rolnik lub jego domownik lub małżonek rolnika (\$2) i wyraźnie przeznaczało pomoc na prowadzanie działalności nierolniczych $\mathrm{w}$ zakresie wynajmu pokoi, sprzedaży posiłków domowych i świadczenia innych usług związanych z pobytem turystów w gospodarstwie rolnym ( $\$ 3$ ust. 1 lit. b).

PROW 2007-2013, podobnie jak SPO Rol., dawał rolnikom możliwość poprawy dochodowości gospodarstw rolnych poprzez podejmowanie określonych działalności nierolniczych (turystyki, rzemiosła), realizujących wielofunkcyjny model rozwoju sektora rolnego i obszarów wiejskich.

3. Program Rozwoju Obszarów Wiejskich na lata 2014-2020 został zatwierdzony przez Komisję Europejską 12 grudnia 2014 r. Będzie realizował wszystkie sześć priorytetów wyznaczonych w nowym okresie programowania dla unijnej polityki rozwoju obszarów wiejskich ${ }^{14}$.

Program nie wskazuje wprost agroturystyki jako elementu rozwoju obszarów wiejskich. Jednak w świetle szans, określonych w analizie SWOT, rozwoju tych obszarów, takich jak wzrost zainteresowania nimi jako miejscem zamieszkania i odpoczynku, można upatrywać znaczącą rolę do odegrania właśnie dla agroturystyki. Wydaje się ona odpowiednim instrumentem wykorzystania określonych w Programie mocnych stron wsi, takich jak „Duże zasoby pracy i jej relatywnie niskie koszty, wysokie walory kulturowe, przyrodnicze i turystyczne”, stanowiących „potencjał

${ }^{12}$ Ustawa z 7 marca 2007 r. o wspieraniu rozwoju obszarów wiejskich z udziałem środków Europejskiego Funduszu Rolnego na rzecz Rozwoju Obszarów Wiejskich, Dz. U. 2007, Nr 64 poz. 427 ze zm.

${ }^{13}$ Rozporządzenie Ministra Rolnictwa i Rozwoju Wsi z 18 marca 2009 r. w sprawie podziału środków Programu Rozwoju Obszarów Wiejskich na lata 2007-2013 (Dz. U. Nr 48, poz. 388 ze zm.).

${ }^{14}$ Priorytety unijne w zakresie rozwoju obszarów wiejskich określone są w art. 5 rozporządzenia Parlamentu Europejskiego i Rady (UE) nr 1305/2013 z 17 grudnia 2013 r. w sprawie wsparcia rozwoju obszarów wiejskich przez Europejski Fundusz Rolny na rzecz Rozwoju Obszarów Wiejskich (EFRROW) i uchylające rozporządzenie Rady (WE) nr 1698/2005, Dz. Urz. UE L 347/487 z 20 grudnia 2013 r. 
dla rozwoju kraju i rozwoju lokalnego"15. Ten rodzaj działalności daje również możliwość zatrudnienia poza rolnictwem bez zmiany miejsca zamieszkania bezrobotnym mieszkańcom wsi, których wysoka liczba jest „zasadniczym problemem rozwojowym obszarów wiejskich”16. Ponadto można stwierdzić, że agroturystyka, ze względu na jej powiązanie z obszarami wiejskimi i rolnictwem, a także relatywnie niewysokie wymogi w zakresie wykształcenia i kwalifikacji zawodowych do jej wykonywania, może być rozwiązaniem problemu, ,niskich i niedopasowanych do potrzeb rynku pracy kwalifikacji mieszkańców obszarów wiejskich, ograniczających możliwość znalezienia zatrudnienia poza rolnictwem" ${ }^{17}$.

Jeżeli chodzi o wsparcie agroturystyki, w PROW 2014-2020 nie ma środków przeznaczonych specjalnie na ten rodzaj działalności. Są przewidziane działania, takie jak ,,premie na rozpoczęcie działalności pozarolniczej” oraz „płatności dla rolników przekazujących małe gospodarstwa”, skierowane na podejmowanie pozarolniczej działalności gospodarczej ${ }^{18}$. Wpisują się one w realizację priorytetu 6: „zwiększania włączenia społecznego, ograniczania ubóstwa i promowania rozwoju gospodarczego na obszarach wiejskich”, a dokładniej - celu szczegółowego 6a: „ułatwiania różnicowania działalności, zakładania i rozwoju małych przedsiębiorstw, a także tworzenia miejsc pracy"19.

Nie zostały jeszcze wydane rozporządzenia wykonawcze, dlatego rozważania ograniczą się do analizy działań opisanych w Programie. Rozporządzenia określą dokładnie rodzaje pozarolniczej działalności gospodarczej objętej działaniami.

W ramach działania ,premie na rozpoczęcie działalności pozarolniczej” przewidziano pomoc na podejmowanie pozarolniczej działalności gospodarczej na obszarach wiejskich. Wsparcie nie dotyczy działalności już prowadzonej. Płatność w wysokości 100 tys. złotych, jako pomoc de minimis, będzie wypłacana $\mathrm{w}$ dwóch ratach: $80 \% \mathrm{w}$ pierwszej racie i $20 \%$ - w drugiej.

Beneficjentem działania może być rolnik, małżonek rolnika lub domownik, ubezpieczony na podstawie przepisów o ubezpieczeniu społecznym rolników z mocy ustawy i w pełnym zakresie ${ }^{20}$. Zakres podmiotowy

${ }^{15}$ PROW 2014-2020, s. 46.

${ }^{16}$ Analiza SWOT PROW 2014-2020.

${ }^{17}$ Analiza SWOT PROW 2014-2020.

${ }^{18}$ Działania zostały określone na podstawie art. 19 rozporządzenia (UE) nr 1305/2013.

${ }^{19}$ Zob. art. 4 ust. 6 rozporządzenia UE 1305/2013.

${ }^{20}$ Należy dodać, że z omawianego działania „Premie na rozpoczęcie działalności pozarolniczej” nie będą mogli skorzystać beneficjenci programów: Różnicowanie w kierunku działal- 
nie jest zatem ograniczony jedynie do osoby rolnika, co umożliwia mu kontynuowanie prowadzenia gospodarstwa rolnego, a małżonce lub innym domownikom - uzupełnianie dochodów gospodarstwa. $Z$ jednej strony jest to sytuacja korzystna właśnie dla agroturystyki, cechującej się powiązaniem usług turystycznych $\mathrm{z}$ działalnością rolniczą, przez ich świadczenie w „czynnym” gospodarstwie rolnym, w którym faktycznie prowadzona jest uprawa lub hodowla zwierząt. Z drugiej strony agroturystyka w rozumieniu art. 3 u.s.d.g. powinna być wykonywana przez rolnika, przy ewentualnej pomocy małżonka i domowników.

Kryteria wyboru przyznają szczególną preferencję dla wnioskodawcy, który jest beneficjentem działania „Płatności dla rolników przekazujących małe gospodarstwa". Taka konstrukcja warunków stanowi dodatkową zachętę dla rolników do rezygnacji z prowadzenia gospodarstwa rolnego, objętego systemem wsparcia małych gospodarstw i przekazania go innym rolnikom, chcącym powiększyć swoje gospodarstwa, aby poprawić jego dochodowość. Jest odpowiedzią na zbyt rozdrobnioną strukturę agrarną i niską dochodowość gospodarstw rolnych.

Pomoc przeznaczona jest dla gospodarstw o niskiej produktywności, tj. takich, których wielkość ekonomiczna jest nie większa niż 15 tys. euro $^{21}$, w celu poprawy jego dochodowości przez dywersyfikację w kierunku działalności pozarolniczej. Działanie jest jednym z dwóch kierunków realizacji założenia PROW „reorientacji gospodarstw” ${ }^{22}$, w myśl którego gospodarstwa powinny zwiększać produkcję na bardziej dochodową lub rozpocząć działalność pozarolniczą.

Kolejnym warunkiem udzielenia płatności jest przyznanie za rok poprzedzający rok złożenia wniosku o przyznanie pomocy płatności do gruntów rolnych wchodzących w skład gospodarstwa rolnego, w którym pracuje wnioskodawca ${ }^{23}$. Z powyższego wynika, że samo istnienie gospodarstwa rolnego nie jest wystarczającym warunkiem. Działanie odnosi się bowiem do gospodarstw, w których faktycznie jest prowadzona działal-

ności nierolniczej - PROW 2007-2013; Premia dla młodych rolników - PROW 2014-2020; Restrukturyzacja małych gospodarstw - PROW 2014-2020.

${ }^{21}$ Wielkość ekonomiczna gospodarstwa rolnego to całkowita roczna standardowa produkcja gospodarstwa, wyrażona w euro. Wielkość ekonomiczna jest liczona zgodnie z metodologią UE zawartą w rozporządzeniu Komisji (WE) nr 1242/2008 z 8 grudnia 2008 r. ustanawiającym wspólnotową typologię gospodarstw rolnych. Zob. PROW, s. 144.

${ }^{22}$ Zob. PROW 2014-2020, s. 74.

${ }^{23}$ Zob. ustawę z 5 lutego 2015 r. o płatnościach w ramach systemów wsparcia bezpośredniego, Dz. U. Nr 0, poz. 308 oraz rozporządzenie Ministra Rolnictwa i Rozwoju Wsi z 12 marca 2015 r. w sprawie szczegółowych warunków i trybu przyznawania płatności bezpośrednich i płatności niezwiązanej do tytoniu, Dz. U. Nr 0, poz. 351. 
ność rolnicza, tzn. ich grunty utrzymywane są w odpowiednim stanie kwalifikującym do otrzymania płatności do gruntów rolnych ${ }^{24}$.

Wskazany warunek wyklucza podmioty posiadające grunty rolne w celach inwestycyjnych lub innych pozarolniczych ${ }^{25}$. Wymóg utrzymywania gruntów w odpowiednim stanie nie jest rozciągnięty na kolejne lata po uzyskaniu płatności, z czego wynika, że nie ma obowiązku kontynuowania $\mathrm{w}$ gospodarstwie rolnym działalności rolniczej.

Gospodarstwo rolne, w którym pracuje wnioskodawca, powinno być położone $\mathrm{w}$ miejscowościach poniżej 5 tys. mieszkańców ${ }^{26}$. Chodzi zapewne o skierowanie wsparcia na obszary wiejskie, na których ze względu na małe zaludnienie trudniej jest znaleźć pracę poza rolnictwem. Wnioskodawca musi przedłożyć biznesplan planowanej działalności pozarolniczej, zakładający jej prowadzenie na obszarze powyżej zdefiniowanym.

Kryteria wyboru mogą w szczególności preferować operacje realizowane przez osoby, zamieszkujące na terenie powiatów o najwyższym poziomie bezrobocia w województwie i które mają odpowiednie kwalifikacje z zakresu prowadzenia działalności pozarolniczej przewidzianej w biznesplanie. Przez kryterium „odpowiednich kwalifikacji”, które zapewne zostanie bliżej scharakteryzowane $\mathrm{w}$ rozporządzeniu, prawdopodobnie będzie można rozumieć posiadanie doświadczenia w danej branży lub certyfikatów ukończenia szkoleń, kursów lub studiów.

W wyniku uruchomienia działalności powinno nastąpić utworzenie co najmniej jednego miejsca pracy w przeliczeniu średniorocznym (również samozatrudnienie). Przy czym mogą być preferowane operacje zakładające utworzenie dodatkowych, poza samozatrudnieniem, miejsc pracy

${ }^{24}$ Zgodnie z art. 32 ust. 2 rozporządzenia Parlamentu Europejskiego i Rady (UE) nr 1307/2013 z 17 grudnia 2013 r. (Dz. Urz. UE L 347/608 z 20 grudnia 2013 r.) grunty kwalifikujące się do płatności to każda powierzchnia użytków rolnych (grunty orne, trwałe użytki zielone, pastwiska trwałe lub uprawy trwałe, w tym szkółki i zagajniki o krótkiej rotacji) wykorzystywana przez cały rok kalendarzowy (z wyjątkiem przypadków działania siły wyższej lub okoliczności nadzwyczajnych) do prowadzenia działalności rolniczej lub wykorzystywana głównie do prowadzenia działalności rolniczej, w tym obszary, które w dniu 30 czerwca $2003 \mathrm{r}$. nie były utrzymywane w dobrej kulturze rolnej. Definicja działalności rolniczej określona jest w art. 4 rozporządzenia UE nr 1307/2013.

${ }^{25}$ Wyłączone ze wsparcia będą obszary wykorzystywane jako lotniska, boiska sportowe lub pola golfowe (zob. § 3 rozporządzenia Ministra Rolnictwa i Rozwoju Wsi z 2015 r. w sprawie szczegółowych warunków i trybu przyznawania płatności bezpośrednich i płatności niezwiązanej do tytoniu).

${ }^{26} \mathrm{~W}$ miejscowości należącej do: o gminy wiejskiej lub o gminy miejsko-wiejskiej, z wyłączeniem miast liczących powyżej 5 tys. mieszkańców, lub o gminy miejskiej z wyłączeniem miejscowości liczących powyżej 5 tys. mieszkańców. 
w przeliczeniu na pełne etaty średnioroczne. Jest to odpowiedź na drugą zdefiniowaną w PROW potrzebę „tworzenia możliwości zatrudnienia poza rolnictwem bez zmiany miejsca zamieszkania" ${ }^{27}$. Nowością w aktualnym PROW jest szczególna preferencja dla operacji o charakterze innowacyjnym ${ }^{28}$ (trudność $\mathrm{w}$ weryfikacji w związku z brakiem definicji innowacji.).

Jak wspomniano, omawiane działanie zachęca do dywersyfikacji działalności, nie wymagając expressis verbis ani rezygnacji z prowadzenia gospodarstwa rolnego, ani kontynuowania działalności rolniczej. Należy jednak zwrócić uwagę na istotny i brzemienny w skutkach warunek zobowiązania się beneficjenta do podlegania ubezpieczeniu społecznemu na podstawie przepisów o systemie ubezpieczeń społecznych oraz rezygnacji z ubezpieczenia emerytalno-rentowego na podstawie przepisów o ubezpieczeniu społecznym rolników do dnia upływu okresu związania celem.

Nie jest jasne, co należy rozumieć przez dzień upływu okresu związania celem. Zapewne wyjaśni to rozporządzenie. W PROW 2007-2013 okres ten wynosił 5 lat. W każdym razie przez kilkuletni okres prowadzenia działalności gospodarczej beneficjent Programu będzie musiał opłacać składki na ubezpieczenie społeczne i emerytalno-rentowe w Zakładzie Ubezpieczeń Społecznych (ZUS) i nie wolno mu podlegać ubezpieczeniu w Krajowym Systemie Ubezpieczeń Społecznych Rolników (KRUS).

Należy zauważyć, że powyższy warunek nie wpisuje się w art. 5a ustawy o ubezpieczeniu społecznym rolników ${ }^{29}$. Pozbawia osoby rozpoczynające prowadzenie pozarolniczej działalności gospodarczej, które podlegały ubezpieczeniu społecznemu rolników w pełnym zakresie z mocy ustawy nieprzerwanie przez co najmniej 3 lata, możliwości dalszego podlegania temu ubezpieczeniu $\mathrm{w}$ okresie prowadzenia pozarolniczej działalności gospodarczej.

Ponadto jeżeli beneficjent omawianego działania, urodzony po 31 grudnia 1948 r., który nie miał ustalonego prawa do emerytury rolniczej, po upływie okresu związania celem byłby zainteresowany powrotem do

\footnotetext{
${ }^{27}$ PROW 2014-2020, s. 70.

${ }^{28}$ Innowacje - zastosowanie lub wprowadzenie nowych lub ulepszonych produktów, procesów (technologii), metod organizacji lub marketingu przez praktyczne wykorzystanie (PROW, s. 144). Wsparcie innowacji jest kluczowym priorytetem dla rozwoju obszarów wiejskich w nowej WPR i powinno być włączone do wszystkich priorytetów przyjętych przez państwa członkowskie w PROW. Zob. priorytety unijne w zakresie rozwoju obszarów wiejskich w art. 5 rozporządzenia UE 1305/2013.

${ }^{29}$ Ustawa z 20 grudnia 1990 r. o ubezpieczeniu społecznym rolników, Dz. U. 1991, Nr 7 poz. 24 ze zm. (dalej jako: u.u.s.r.).
} 
systemu ubezpieczenia społecznego rolników dla wypracowania potrzebnych lat do emerytury rolniczej, okres, przez który podlegał ubezpieczeniu w ZUS, w myśl art. 20 ust. 3 ustawy o ubezpieczeniu społecznych rolników nie zostanie doliczony do okresu ubezpieczenia w KRUS $^{30}$. W takim przypadku okresy opłacania składek na ubezpieczenie rolnicze zostaną uwzględnione do ustalenia prawa do emerytury oraz jej wysokości z systemu powszechnego (ZUS) ${ }^{31}$. Można zauważyć, że działania zachęcające rolników do podejmowania działalności gospodarczej i przejścia do powszechnego systemu ubezpieczeń społecznych wpisują się w zalecenia Rady Unii Europejskiej w sprawie likwidacji KRUS i objęcia rolników powszechnym ubezpieczeniem społecznym ${ }^{32}$.

Poza powyższymi kwestiami związanymi z zaliczaniem okresów składkowych do obliczenia wysokości świadczenia emerytalnego niekorzystnie wypada również kalkulacja wysokości składek ubezpieczenia, o których mowa w przepisach o systemie ubezpieczeń społecznych - są one o wiele wyższe od tych na ubezpieczenie społeczne rolników. Jak wspomniano, w myśl omawianego działania rolnicy prowadzący, obok rolniczej, również pozarolniczą działalność gospodarczą nie mogliby skorzystać z możliwości pozostawania w systemie ubezpieczeń społecznych rolników (w myśl art. 5a u.u.s.r.) i opłacania składek na ubezpieczenie emerytalno-rentowe w podwójnym wymiarze (na podstawie art. 17 ust. 2 u.u.s.r.). Kalkulacja dwukrotności składek dla gospodarstwa rolnego do 50 ha, (działanie dotyczy bowiem małych gospodarstw), wypada korzystniej w porównaniu z wysokością składek opłacanych w ZUS, nawet przy uwzględnieniu 50\% obniżki składek w pierwszych dwóch latach prowadzenia działalności gospodarczej ${ }^{33}$.

${ }^{30} \mathrm{~W}$ wyniku nowelizacji przepisów ustawy o ubezpieczeniu społecznym rolników w drodze ustawy z 21 listopada 2008 r. o emeryturach kapitałowych (Dz. U. 2008, Nr 228, poz. 1507 ze zm.), rolnicy urodzeni po 31 grudnia 1948 r. nie mają prawa doliczać do stażu w KRUS okresów, w których podlegali ubezpieczeniom w ZUS (z tytułu pracy poza rolnictwem). Taka osoba, aby uzyskać prawo do emerytury rolniczej, musi przez co najmniej 25 lat podlegać wyłącznie rolniczemu ubezpieczeniu emerytalnemu. Okresy składkowe w ZUS mogą natomiast być uwzględniane do ustalenia prawa i wysokości renty rolniczej z tytułu niezdolności do pracy.

${ }^{31}$ Zgodność art. 20 ust. 3 u.u.s.r. z Konstytucją potwierdził SN w wyroku z 9 marca 2011 r., III UK 83/10.

${ }^{32}$ Zob. Zalecenie Rady w sprawie krajowego programu reform Polski na 2015 r. oraz zawierające opinię Rady na temat przedstawionego przez Polskę programu konwergencji na $2015 \mathrm{r}$. Bruksela, 13 maja 2015 r., COM (2015), 270 final.

${ }^{33}$ Obecnie (tj. w II kwartale 2015 r.) składka na ubezpieczenie społeczne rolników dla rolnika prowadzącego jednocześnie pozarolniczą działalność gospodarczą i gospodarstwo rolne wynosi 654 zł kwartalnie. Zob. http://www.krus.gov.pl/krus/krus-w-liczbach/wymiar-kwartalnych- 
Pomoc w wysokości 100 tys. zł może nie zrekompensować wskazanych niekorzystnych skutków. W celu opłacania wysokich składek i wyrównania ewentualnej utraty emerytury z KRUS agroturystyka musiałaby stać się działalnością wystarczająco dochodową, a więc być może dominującą w stosunku do działalności rolniczej prowadzonej w małym gospodarstwie. Jednak pojawia się wątpliwość, czy agroturystyka ze względu na swoją specyfikę (zwłaszcza jej sezonowy charakter) mogłaby przynosić odpowiednio wysokie zyski ${ }^{34}$.

Ponadto warto zauważyć, że prowadzenie agroturystyki w większych rozmiarach, polegającej na wynajmie ponad 5 pokoi lub wynajmie domków turystycznych lub odpłatnym świadczeniu dodatkowych usług, spowoduje obowiązek zapłaty podatku dochodowego od osób fizycznych od przychodu uzyskanego z tej działalności ${ }^{35}$ oraz podatku od nieruchomości związanej z wykonywaniem działalności gospodarczej. Budynki mieszkalne, w których prowadzony jest wynajem turystom do 5 pokoi gościnnych, nie są uważane za budynki przeznaczone na prowadzenie działalności gospodarczej ${ }^{36}$. W przypadku przekroczenia powyższej liczby powierzch-

skladek-na-ubezpieczenie-spoleczne-rolnikow/. Natomiast minimalne składki ZUS dla osób prowadzących działalność gospodarczą za miesiące od kwietnia do grudnia 2015 r. wynoszą 1092,28 zł miesięcznie, a dla osób rozpoczynających działalność gospodarczą - 446,20 zł miesięcznie przez okres 24 miesięcy od dnia rozpoczęcia wykonywania działalności gospodarczej. Zob. na http://zus.pox.pl/skladki-zus-2015-dzialalnosc-gospodarcza.htm.

${ }^{34} \mathrm{Na}$ temat dochodowości gospodarstw agroturystycznych zob. np. A. Wiśniewska, Dochodowość uslug agroturystycznych w gospodarstwach kaszubskiej gminy Brusy, „Słupskie Prace Geograficzne” 2008, nr 5, s. 65-74; J. Cichowska, Sytuacja ekonomiczna badanych gospodarstw agroturystycznych, infrastruktura i ekologia terenów wiejskich, „Infrastructure and Ecology of Rural Areas" 2010, nr 2, s. 85-95; I. Kurtyka, Uwarunkowania rozwoju turystyki wiejskiej na terenie Dolnego Śląska ze szczególnym uwzględnieniem obszarów górzystych, „Nierówności Społeczne a Wzrost Gospodarczy" 2012, z. 29, s. 202-211; idem, Ekonomiczne aspekty turystyki wiejskiej na przykładzie Parku Krajobrazowego Dolina Baryczy, „,Roczniki Naukowe SERiA" 7, 2010, z. 2, s. 164-168; idem, Turystyka wiejska i agroturystyka szansa poprawy dochodowości gospodarstw indywidualnych na Dolnym Ślasku, Monografie - Prace zbiorowe Wyższej Szkoły Zarządzania i Edukacji we Wrocławiu, Wrocław 2010, s. 87- 98.

${ }^{35}$ Zwolnione $\mathrm{z}$ podatku dochodowego od osób fizycznych są jedynie, w myśl art. 21 ust. 1 pkt 43 ustawy z 26 lipca 1991 r. o podatku dochodowym od osób fizycznych, Dz. U. 1991, Nr 80, poz. 350 ze zm. (dalej jako: u.p.d.o.f.): ,dochody uzyskane z tytułu wynajmu pokoi gościnnych, w budynkach mieszkalnych położonych na terenach wiejskich w gospodarstwie rolnym, osobom przebywającym na wypoczynku oraz dochody uzyskane z tytułu wyżywienia tych osób, jeżeli liczba wynajmowanych pokoi nie przekracza 5". Na temat prawnopodatkowych aspektów agroturystyki zob. A. Kapała, Prawnopodatkowe aspekty agroturystyki, „Przegląd Prawa Rolnego" 2010, $\mathrm{nr}$ 1, s. 73-96.

${ }^{36}$ W myśl art. 1a ust. 2 ustawy o podatkach i opłatach lokalnych (Dz. U. 1991, Nr 9, poz. 31) w rozumieniu ustawy za działalność gospodarczą nie uważa się „wynajmu turystom pokoi gościnnych w budynkach mieszkalnych znajdujących się na obszarach wiejskich przez osoby ze 
nia wszystkich wynajmowanych pokoi podlega opodatkowaniu podatkiem od nieruchomości jako część budynku mieszkalnego zajętego na prowadzenie działalności gospodarczej. Wskazany obowiązek w zakresie podatku od nieruchomości powstanie również w odniesieniu do tej części budynku mieszkalnego, w którym prowadzone są sprzedaż posiłków domowych lub inne usługi. Warto dodać, że podatek od nieruchomości przeznaczonej na działalność gospodarczą jest znacznie wyższy od podatku od budynków mieszkalnych ${ }^{37}$.

W kwestii rozmiaru prowadzonej działalności agroturystycznej względem działalności rolniczej art. 3 u.s.d.g. nie wprowadza warunku przewagi tej drugiej względem pierwszej. Co więcej, nie określa wprost wymogu jednoczesnego prowadzenia działalności rolniczej lub wytwórczej w rolnictwie, posługując się jedynie kryterium podmiotowym, określając rolnika jako podmiot prowadzący agroturystykę, oraz przedmiotowym, wskazując na gospodarstwo rolne jako miejsca prowadzenia agroturystyki.

Ustawa nie wyjaśnia, jak należy rozumieć użyte terminy. Nie jest jasne, czy gospodarstwo rolne należy w tym przypadku pojmować $\mathrm{w}$ sensie funkcjonalnym, czy wystarczy ujęcie przedmiotowe. Przyjęcie tego drugiego rozumienia powoduje, że do wykonywania agroturystyki wystarczy posiadanie gruntów rolnych o powierzchni przekraczającej $1 \mathrm{ha}^{38}$. Jednak odwołanie się w zakresie pojęcia rolnika do ustawy o kształtowaniu ustroju rolnego i zawartej $\mathrm{w}$ niej definicji rolnika indywidualnego, który zgodnie z jej art. 6 - prowadzi osobiście gospodarstwo rolne, daje podstawy do stwierdzenia, że wykonywanie działalności rolniczej jest warunkiem kwalifikacji agroturystyki. Przez prowadzenie gospodarstwa rolnego według doktryny należy bowiem rozumieć prowadzenie działalności rolniczej ${ }^{39}$. Odwołanie się do pojęcia rolnika z ustawy o ubezpieczeniu

stałym miejscem pobytu $\mathrm{w}$ gminie położonej na tym terenie, jeżeli liczba pokoi przeznaczonych do wynajęcia nie przekracza 5".

${ }^{37}$ Zob. art. 5 ust. 1 pkt 2 ustawy o podatkach i opłatach lokalnych, a także Obwieszczenie Ministra Finansów z 7 sierpnia 2014 r. w sprawie górnych granic stawek kwotowych podatków i opłat lokalnych w 2015 r., Monitor Polski 2014, poz. 718.

${ }^{38}$ Zob. definicję gospodarstwa rolnego w art. 2 ust. 1 ustawy z 15 listopada 1984 r. o podatku rolnym (Dz. U. 1984, Nr 52, poz. 268).

${ }^{39}$ Według R. Budzinowskiego gospodarstwo rolne można ująć z funkcjonalnego punktu widzenia, które obejmuje określoną działalność, zob. idem, Pojęcie gospodarstwa rolnego wedtug wedlug k.c. (rozważania na tle art. $55^{3}$ k.c.), „Ruch Prawniczy, Ekonomiczny i Socjologiczny” 1991, z. 3, s. 65. Zob. także idem, Koncepcja gospodarstwa rolnego w prawie rolnym, Wydawnictwo Naukowe UAM, Poznań 1992, s. 150; idem, Gospodarstwo rolne i przedsiębiorstwo rolne, w: A. Stelmachowski (red.), Prawo rolne, Warszawa 2005, s. 64. 
społecznym rolników również pozwala na przyjęcie takiej interpretacji, art. 6 pkt 1 u.u.s.r. wyraźnie bowiem definiuje rolnika jako osobę prowadzącą „osobiście i na własny rachunek, działalność rolniczą w pozostającym w jej posiadaniu gospodarstwie rolnym".

Można zatem przyjąć, że usługi przyjmowania i gościnności prowadzone przez rolnika $\mathrm{w}$ gospodarstwie rolnym, w którym wykonywana jest choćby minimalna działalność rolnicza, mogą się kwalifikować jako agroturystyka w rozumieniu art. 3 u.s.d.g., bez względu na jej rozmiar i dochodowość. Limit 5 pokoi został wprowadzony art. 21 ust. 1 pkt 43 u.p.d.o.f. jedynie dla celów zwolnienia z podatku dochodowego. A contrario, jeżeli w gospodarstwie rolnym nie jest prowadzona żadna działalność rolnicza, usługi w nim świadczone nie są agroturystyką w rozumieniu art. 3 u.s.d.g.

Dla celów rozważań teoretycznoprawnych warto dodać, że według włoskiego ustawodawstwa i doktryny agroturystyka powinna być rozumiana jako działalność nieprzeważająca wobec podstawowej działalności rolniczej. Przewidziane w prawie włoskim kryteria przewagi działalności rolniczej względem agroturystyki uzasadniają możliwość zachowania przez rolnika (przedsiębiorcę rolnego) swojego uprzywilejowanego statusu prawnego przy prowadzeniu obu działalności.

4. Drugim działaniem przewidującym dofinansowanie na uruchomienie działalności gospodarczej są „Płatności dla rolników przekazujących małe gospodarstwa” (poddziałanie: „Płatności na rzecz rolników kwalifikujących się do systemu dla małych gospodarstw, którzy trwale przekazali swoje gospodarstwo rolne innemu rolnikowi”). Pomoc przyznawana jest tym rolnikom, którzy kwalifikują się do systemu dla małych gospodarstw $^{40}$, ustanowionego $\mathrm{w}$ rozporządzeniu $\mathrm{w}$ sprawie płatności bezpośrednich i trwale przekazują (w drodze sprzedaży lub darowizny) swoje gospodarstwo rolne innemu rolnikowi.

Gospodarstwo przejmujące grunty od beneficjenta musi posiadać lub osiągnąć po przejęciu gruntów od beneficjenta działania co najmniej wielkość odpowiadającą średniej wielkości gospodarstwa w Polsce lub średniej wielkości gospodarstwa $\mathrm{w}$ danym województwie, jeśli średnia powierzchnia gospodarstw w danym województwie jest większa niż średnia wielkość gospodarstwa w Polsce. Działanie ma być zatem instrumentem poprawy struktury agrarnej.

\footnotetext{
${ }^{40}$ Określenie systemu dla małych gospodarstw, o których mowa w art. 19 ust. 1 lit. a ppkt (iii) rozporządzenia (UE) nr 1305/2013.
} 
Po przekazaniu gospodarstwa beneficjent nie będzie podlegał ubezpieczeniu społecznemu rolników w Kasie Rolniczego Ubezpieczenia Społecznego. Pojawia się tu ten sam problem utraty składek emerytalno-rentowych zasygnalizowany wyżej przy omawianiu poprzedniego działania.

Roczna stawka pomocy odpowiada $120 \%$ rocznej płatności, do której otrzymania beneficjent kwalifikuje się $\mathrm{w}$ ramach systemu dla małych gospodarstw. Opisana wyżej stawka pomocy przysługuje za rok, w którym beneficjent trwale przekazuje swoje gospodarstwo, i lata następne, do roku 2020 włącznie. Pomoc wypłaca się jednorazowo. Jak wspomniano wyżej, beneficjentom powyższego działania szczególne preferencje wyboru przyznaje działanie „Pomoc na rozpoczęcie pozarolniczej działalności gospodarczej na obszarach wiejskich". A zatem rolnicy trwale przekazujący swoje gospodarstwa mogą otrzymać płatności z obu omawianych działań.

Chociaż beneficjentem działania jest rolnik, to w celu uzyskania wsparcia musi ten status utracić oraz wyzbyć się gospodarstwa rolnego, czyli miejsca, w którym agroturystyka powinna być prowadzona. $\mathrm{Z}$ uwagi na ten warunek należy stwierdzić, że powyższe działanie nie jest odpowiednim źródłem wsparcia dla agroturystyki, będącej aktywnością powiązaną z działalnością rolniczą i gospodarstwem rolnym.

5. Opisane działania przyznają płatności na uruchomienie działalności gospodarczej i niewątpliwie stanowią instrument wsparcia rozwoju gospodarczego i strukturalnego rolnictwa i obszarów wiejskich. Jednakże rola agroturystyki w rozwoju obszarów wiejskich, rozumianej zgodnie $\mathrm{z}$ art. 3 u.s.d.g., czyli działalności wykonywanej obok działalności rolniczej, zwolnionej z podlegania przepisom ustawy o swobodzie działalności gospodarczej, nie została uwzględniona. Rolnik zainteresowany otrzymaniem z PROW płatności na jej rozpoczęcie będzie musiał taką działalność zarejestrować. Co więcej, chociaż pomoc skierowana jest do podmiotów ubezpieczonych w KRUS, jej uzyskanie w przypadku omówionych działań wiąże się $\mathrm{z}$ obowiązkiem rezygnacji ze społecznego ubezpieczenia rolników i podlegania wyłącznie ubezpieczeniu społecznemu. Beneficjenci tracą w ten sposób swój uprzywilejowany status w zakresie ubezpieczenia społecznego i możliwość skorzystania z uprawnienia wskazanego $\mathrm{w}$ art. 5 lit. a u.u.s.r. Widoczny jest zatem brak spójności warunków PROW z przywilejami przewidzianymi przez wymienione powyżej przepisy prawa (art. 3 u.s.d.g. $i$ art. 5 lit. a u.u.s.r.). 
Omawiane działania bardziej zachęcają podmioty prowadzące nierentowne małe gospodarstwa rolne do podjęcia działalności gospodarczej niż do utrzymywania i uzupełniania działalności rolniczej. W przypadku działania „Premie na rozpoczęcie działalności pozarolniczej” rolnik zachowuje gospodarstwo rolne i może (ale nie musi) nadal prowadzić w nim działalność rolniczą. Jak jednak wspomniano, obowiązek rezygnacji z ubezpieczenia w KRUS może skłaniać rolników do zaangażowania się na cały etat w pozarolniczą działalność gospodarczą w celu wypracowania odpowiednich dochodów, pozwalających na pokrycie wyższych składek w ZUS i rekompensujących ewentualną niższą emeryturę. W przypadku drugiego działania, z powodu wyzbycia się gospodarstwa rolnego rolnik traci swój status zarówno formalnie, jak $\mathrm{i} \mathrm{w}$ praktyce. $\mathrm{W}$ takich sytuacjach prowadzona działalność przyjmowania turystów i gościnności nie może kwalifikować się jako agroturystyka.

Kryteria określania agroturystyki, a co za tym idzie - wymogi uzyskania płatności rzutujące na sposób jej prowadzenia, powinny uwzględniać warunki ustanowione $\mathrm{w}$ art. 3 u.s.d.g. Warto ponadto mieć na uwadze poglądy wybitnych prawników agrarystów, którzy twierdzą, że „prowadzący działalność agroturystyczną powinni być i powinni pozostać rolnikami" ${ }^{41}$ oraz że warto „torować drogę rolniczo-komplementarnej turystyce" ${ }^{42}$.

Oczywiście kształt PROW 2014-2020 określony jest przepisami rozporządzenia 1305/2013, które nie przewidują odrębnego wsparcia specjalnie na agroturystykę, lecz pomoc na rozpoczęcie działalności gospodarczej (art. 19 ust. 1 pkt a) lub pomoc na inwestycje w tworzenie i rozwój działalności pozarolniczej (art. 19 ust. 1 pkt b). Do państw członkowskich jednak należy określenie szczegółowych kryteriów uzyskania pomocy, na które wpływ może mieć wewnętrzne ustawodawstwo, pod warunkiem że nie będą sprzeczne z przepisami UE.

Dla porównania warto wskazać, że we Włoszech w regionalnych programach rozwoju obszarów wiejskich przewidziane jest wsparcie w ramach działania „różnicowanie w kierunku działalności pozarolniczych” na agroturystykę rozumianą zgodnie $\mathrm{z}$ obowiązującym tam prawem,

${ }^{41}$ Tę opinię A. Carozzy przytacza N. Ferrucci, L’agriturismo: icona della trasversalità dell'agricoltura tra impresa, alimentazione, ambiente e paesaggio, „Rivista di Diritto Agrario” 2007, z. 8, s. 680 .

${ }^{42}$ Tak M. Błażejczyk, Prawno-rolne aspekty rozwoju wiejskiej turystyki, „Prawo Rolne” 1993, nr 3, s. 81 . 
tj. art. 2135 wł. k.c. ${ }^{43}$, czyli działalność wykonywaną w ramach rolnego reżimu prawnego ${ }^{44}$. Nie ma zatem wymogu rejestrowania działalności gospodarczej i opłacania $\mathrm{z}$ tego tytułu składek na ubezpieczenie społeczne. Wskazanego warunku nie wprowadza też art. 19 ust. 1 rozporządzenia UE 1305/2013 w odniesieniu do działania określonego w pkt b. Podmiotowa sytuacja prawna włoskiego przedsiębiorcy rolnego korzystającego ze wsparcia na agroturystykę pozostaje zatem bez zmian. Ponadto pomoc przewidziana jest nie tylko na uruchamianie działalności agroturystycznej, ale też i na rozwój działalności już prowadzonej ${ }^{45}$. Jest to zgodne z wyżej wymienionym art. 19 ust. 1 lit. b rozporządzenia UE 1302/2013.

Tak skonstruowane działania mogą stanowić przykład dla Polski. Zachęcają rolników do podejmowania i rozwijania agroturystyki jako aktywności pozarolniczej, uzupełniającej działalność rolniczą, a w szerszej perspektywie - wzmacniającej rolę rolnictwa i gospodarstw rolnych z punktu widzenia ekonomicznego, a także ochrony obszarów wiejskich, rolniczego krajobrazu i środowiska.

\title{
LEGAL DETERMINANTS OF RECEIVING SUPPORT FOR AN AGRITOURISM BUSINESS FROM THE RURAL DEVELOPMENT PROGRAMME 2014-2020
}

\author{
Sum mary
}

The deliberations presented in the paper aim to establish whether and to what extent support can be offered under the Rural Development Programme 2014-2020 to farmers planning or already engaged in agritourism. The categorisation of different types of agritourist activity provided in the Programme has been analysed. Regulation (EU)1305/2013 does not provide for any special support for agritourism, but only a business start-up aid (Article 19.1.a) or for investments and creation of non-agricultural activities (Article 19.1.b). It leaves the decision of detailed criteria qualifying for the support to Member States, but makes no mention of the role of agritourism in the development of rural areas, as business conducted alongside ordinary agricultural activity, excluded from the scope of the Act on Freedom of Business Activity.

${ }^{43}$ Dekret królewski z 16 marca 1942 r., nr 262, Przyjęcie tekstu kodeksu cywilnego, „Gazzetta Ufficiale" nr 79 z 4 kwietnia 1942 r.

${ }^{44}$ Szerzej na temat prawnej regulacji agroturystyki we Włoszech zob. A. Kapała, Prawne pojęcie..., oraz eadem, Agroturystyka jako rodzaj działalności rolniczej w prawie włoskim, „Przegląd Prawa Rolnego” 2007, nr 2, s. 203-218.

45 Zob. np. PROW 2014-2020 Regionu Marche (poddziałanie 6.4, Azione A), PROW 2014-2020 Regionu Sycylia (poddziałanie 6.4) oraz PROW 2014-2020 Regionu Campania (poddziałanie 6.4.1). 


\title{
LA POSSIBILITÀ DI OTTENERE DEI FINANZIAMENTI PER L'APERTURA DI UN AGRITURISMO CON IL PROGRAMMA DI SVILUPPO RURALE 2014-2020
}

\author{
Riassunto
}

L'obiettivo della discussione è di determinare se e in quale misura il Programma di Sviluppo rurale 2014-2020 preveda il sostegno agli agricoltori che stanno per avviare oppure stanno già esercitando l'attività agroturistica. Ad analisi sono state sottoposte le misure definite nel Programma nell'ambito della diversificazione dell'attività. Il Regolamento 1305/2013 non prevede sostegno separato all'agriturismo, ma aiuti all'avviamento di imprese (art. 19 paragrafo 1 lettera a) oppure aiuti agli investimenti nella creazione e nello sviluppo di attività extra-agricole (art. 19 paragrafo 1 lettera b). Spetta agli Stati membri definire i criteri specifici per concedere l'aiuto. Tuttavia, il ruolo dell'agriturismo per lo sviluppo rurale, inteso come attività che affianca l'attività agricola, esente dall'essere soggetta alle disposizioni di legge sulla libertà di iniziativa economica, non è stato preso in considerazione. 